\title{
Quality of life at levels of physical activity of volunteers from the university community
}

\author{
Erika Da Silva Maciel ${ }^{1,}$, , Roberto Vilarta ${ }^{2}$, Dênis Marcelo Modeneze ${ }^{3}$, Jaqueline Girnos Sonati ${ }^{3}$, \\ Guanis Barros Vilela Junior ${ }^{4}$, Marília Oetterer ${ }^{5}$ \\ ${ }^{1}$ University Center Lutheran of Palmas CEULP-ULBRA, Palmas, TO, Brazil \\ ${ }^{2}$ Titular Professor- State University of Campinas (UNICAMP), University Campus “Zeferino Vaz”, Physical Education Institute, \\ Department for Adapted Physical Activity Studies, Campinas SP, Brazil \\ ${ }^{3}$ State University of Campinas (UNICAMP), University Campus “Zeferino Vaz", Physical Education Institute, Department for Adapted \\ Physical Activity Studies, Campinas SP, Brazil \\ ${ }^{4}$ Masters Program in Physical Education, Methodist University of Piracicaba, Piracicaba, SP, Brazil \\ ${ }^{5}$ Titular Professor-University of São Paulo (USP), "Luiz de Queiroz" College of Agriculture, Food Sciences and Technology Department, \\ Piracicaba SP, Brazil
}

\section{Email address:}

erikasmaciel@gmail.com (E. D. S. Maciel)

\section{To cite this article:}

Erika Da Silva Maciel, Roberto Vilarta, Dênis Marcelo Modeneze, Jaqueline Girnos Sonati, Guanis Barros Vilela Junior, Marília Oetterer. Quality of Life at Levels of Physical Activity of Volunteers from the University Community. American Journal of Health Research.

Vol. 2, No. 5, 2014, pp. 275-283. doi: 10.11648/j.ajhr.20140205.19

\begin{abstract}
The objective of this research was to assess the quality of life of volunteers from the University of São Paulo at different levels of physical activity. To evaluate the quality of life perception, the WHOQOL-bref. Nutritional status was evaluated through the body mass index (BMI). The level of physical activity was measured using the International Physical Activity Questionnaire (IPAQ) (short version typical week). All these instruments were utilized to compose a computerized system of data collection. Among the findings it is highlighted that most of the 1,966 participants are single (65.9\%), undergraduate students (52.6\%) originated from the Campus of São Paulo city (50.9\%), 32.3\% are overweight and 65.5\% meet the recommendation for regular physical activity. It was observed that the most active individuals exhibit higher scores in all areas of life quality which justifies actions to increase physical activity on the academic community.
\end{abstract}

Keywords: Lifestyle, Physical Activity Level, Electronic Data Collection

\section{Introduction}

The Quality of Life (QOL), understood as a concept and practice, has been the subject of academic discussions with repercussions on different layers and sectors of society. In the last decade this concept has attracted the scientific community in to researches that related to sociodemographic and cultural variables, and somatic diseases.

Minayo et al. (1) conceptualizes the quality of life as "the relationship between biological and social aspects mediated by mental, environmental and cultural conditions," this approach is very similar to the World Health Organization (WHO) which refers to the relationship of " perception of and individual of their position in life in the context of culture and value systems in which they live and in relation to their goals, expectations, standards and concerns ", both, thus, emphasizing the issues of individual perception about lifestyle, life condition and health (2).

The concept of QOL by the WHO involves certain features such as subjectivity, self-perception, satisfaction and dissatisfaction, physical, cognitive and affective states and interpersonal relationships, as well as several external environmental conditions and general conditions of life (3). Currently, QOL has been the focus of research also study the relationship between lifestyle and health, especially in interventions with special groups or populations with Chronic Non-Communicable Diseases (NCDs) (4).

Strategies for promoting populations QOL include actions involving healthy diet, physical activity, decreasing tobacco and alcohol consumption (5). These strategies aim 
to minimize risk conditions for NCDs and improve the perception of populations QOL.

In Brazil, 30 years ago, QOL was assessed, in particular, by the conditions of basic sanitation, economic situation and access to health and education. Currently, these factors are still used, however, with the improvement of living conditions of the population, the adoption of a healthy lifestyle also became recognized as an important factor in determining the quality of life (6).

In recent years has been held a collective effort by researchers to clarify the relationships between perceived QOL, specified by domains in different groups and situations, and issues related to lifestyle and health risk conditions, since such relationships are not fully established(4,7,8).

A significant part of the current researches focuses on the study of the relationship between modifiable lifestyle factors, such as everyday physical activity and healthy eating behavior, since they are factors which contribute positively for health maintenance, mitigating the risks to which we are exposed, in particular those related to behavioral changes brought to the process of industrialization(9).

Regular physical activity has been linked to health promotion, and cited as a key factor in improving the quality of life $(10,11)$. Their absence is considered one of the major risk factors for cardiovascular morbimortality $(12,13)$. This phenomenon is observed in both developed countries and developing ones, justifying the need to stimulate the elaboration of campaigns involving approaches for combating inactivity in healthy adult populations as a stimulus for promoting quality of life $(4,8,14)$.

It is recognized that the systematic practice of physical activity induces healthier behaviors that reflect positively on nutritional indicators, such as improved body composition, reducing the percentage of fat and increasing lean body mass, adjustments in rates of cholesterol, triglycerides and blood glucose, control and reduction of blood pressure, increased muscle strength and endurance, and increased bone mineral density $(15,16)$ and to improvement of cardiovascular and respiratory function, reduction in risk factors for atherosclerotic disease, reduce mortality and morbidity, supporting the control of anxiety and depression, increased feelings of well-being, better performance in job-related functions, as well as positive associations with recreational and leisure activities $(17,18,19,20,21)$.

The Higher Education Institutions (HEIs) in the implementation of academic curricular activities of courses in the health field provide specific content in the areas of vocational training, as well as a set of information that qualify citizens about various aspects that contribute to the achievement of quality in life (22). More recently, the actions of programs of Open University of the Third Age (UnATI), targeted for the elderly in many public places in Brazil, located in most part of the southeastern region, being managed by universities or educational institutions are mentioned(23). Another example is the Interdisciplinary Program of Higher Education (ProFIS) which is a pilot program of higher education offered by UNICAMP for students who attended high school in public schools of the city of Campinas (24).

However, the research of quality of life in the university environment features interesting advantages given the social diversity and levels of academic background of people attending this environment, allowing multifactorial reviews of a well established portion of the population, composed by opinion makers with higher levels and relatively higher income compared with other social strata (25).

Faced with this data, research was conducted to evaluate the perceived quality of life, level of physical activity and nutritional status of a university community, aiming to detail the specific contribution of interfering factors in health promotion strategies that can be applied in environments with well-defined income and levels of academic background.

\section{Materials and Methods}

This study was described as an analytical cross sectional research. The study was approved by the Ethics Committee on Human Research of the College of Agriculture "Luiz de Queiroz" (ESALQ-USP) under protocol number 21.

\subsection{Sample}

The sample, non-probabilistic, by convenience, was originally from the academic community of the University of São Paulo (USP) and involved the voluntary participation of students, teachers and workers from the Campi São Paulo, Piracicaba, Pirassununga, São Carlos, Ribeirão Preto, Lorena and Bauru, totaling 1,966 subjects from a population estimated in 108,636 individuals (26).

The invitation to participate was sent via e-mail containing information about research and guidelines to access the questionnaires. Other sources of dissemination such as social networking, informative wall and classroom lectures at the university were also used.

The user ID was defined by individual email and registration number at USP, ensuring that only the university community had access to the instruments. However, this data was not recorded. There was no public identification of the participant. The information about the research and the instruments were hosted at the Study Group and Technological Innovation Extension and Fish Quality (GETEP), at the School of Agriculture Luiz de Queiroz (ESALQ) website. Data collection occurred during two months.

After accessing the survey information, the volunteer could opt for full or partial filling of forms, with the possibility of returning to the forms and complete them later on. Forfeiting the completion of forms could occur at 
any time, simply by not completing the transmission of information.

\subsection{Instruments}

\section{Nutritional Status}

To analyze the nutritional status, the Body Mass Index (BMI) was calculated, where body mass and height were self-reported by the participant and the classification criteria proposed by WHO (5), where BMI between 18.5 to 24,9 was considered normal; between 25.0 to $29.9=$ overweight; between 30 to 34.9 = grade I obesity; between 35.0 to $39.9=$ grade II obesity and over $40=$ obesity class III

\section{Physical Activity Level}

It was measured using the International Physical Activity Questionnaire (IPAQ) short version typical week, which is easy to apply and is inexpensive. The method of IPAQ is an instrument developed to estimate the level of regular practice of physical activity in groups and populations from different countries and socio-cultural contexts. Its formulation was proposed by the International Consensus Group for Physical Activity Measures, under the auspices of WHO with representation from 25 countries (27).

This instrument has been validated for use in young Brazilian adults for Pardini et al. (28). For classification of levels of physical activity were used criteria described by Matsudo et al. (14), according to which the data are provided based on the past week and classify each individual according to the activities that they exert over the days of the week. Such activities can be vigorous when they demand great physical effort and make you breathe much harder than normal or moderate activities, that for its execution, require some physical effort and produce a breath a little harder than normal. Based on the frequency and duration of these activities, it is possible to classify the individual on categories such as Sedentary, Insufficiently active A and B, Active and Very Active.

Quality of Life

The WHOQOL-BREF(29) structured by 4 domains (physical, psychological, social relationships and environment) was used, consisting of 26 questions-facets on Likert five-point scale, with question number 1 and 2 on the general quality of life and the other representing each of the 24 facets. This instrument was adapted from the original instrument, WHOQOL-100 and validated for use in Brazil (30).

\subsection{Analyse}

Data analysis of IPAQ questionnaires and WHOQOLBREF were performed following the methodology proposed by WHO. Frequency analysis for ratings of BMI, physical activity level, income and gender were performed on each campus.

Although it is not a general rule of evaluation of the WHOQOL, the User Manual of the WHOQOL proposes the conversion of the results to a scale from 0 to 100 , corresponding to the same values as the end result of the adoption of all equations provided, this procedure was adopted in the study (2).

Data were subjected to analysis of normality (Kolmogorov and Smirnoff tests) and homoscedasticity. Sample descriptive analysis, frequency analysis for ratings of BMI, level of physical activity, income and gender were performed on each campus.

To analyze the data on quality of life was considered the calculation of Cronbach alpha $(\alpha)$ used to verify the reliability of the scale, ie, the degree to which the measure is free of errors and thus produce consistent results, values above 0.6 are considered acceptable (31).

With interest in comparing the average values of the variables in different categorization criteria was defined the validity of the application of non-parametric tests, due to the ordinal nature of the data and the inadequacy of the application of analysis of variance, supported by noncompliance data unique to the normal distribution. For comparison between groups, we used the Kruskal-Wallis and Wilcoxon test. As a non-parametric test, we selected the Kruskal-Wallis test, suitable for the case of comparing $\mathrm{k}$-samples. In the special case of two test samples is similar to the Wilcoxon test for two independent samples.

The Kruskal-Wallis test was calculated from specific routine and also by approximating the $\mathrm{F}$ test which proves satisfactory and on which is based the application of the approach by the Kruskal-Wallis $t$ test for multiple comparisons of means. The SAS statistical package was used and the significance values of $<0.05$.

\section{Results}

The average age was 30.42 years $( \pm 12.41)$, the majority of participants reported being single $(65.90 \%)$, undergraduate students $(52.6 \%)$ originated from the Campus of São Paulo (50.90\%). As far as smoking, 7\% of the entire sample said that they routinely used cigarette.

The results concerning the distribution of men and women in Campi (Table 1) indicate that women are the majority $(61.60 \%)$ on all campuses, with the exception of Lorena and São Carlos, where the higher frequency of men in the sample was identified.

Table 1. Distribution of participants by gender in USP Campi.

\begin{tabular}{llllll}
\hline \multirow{2}{*}{ Campi } & \multicolumn{6}{l}{ Gender } & \multicolumn{2}{l}{ Female } & Total \\
\cline { 2 - 6 } & \multicolumn{2}{l}{ Male } & N & \% & \\
\cline { 2 - 6 } & $\mathbf{N}$ & $\mathbf{\%}$ & 13 & 56.5 & 23 \\
Bauru & 10 & 43.5 & 26 & 41.9 & 62 \\
Lorena & 36 & 58.1 & 293 & 60.8 & 482 \\
Piracicaba & 189 & 39.2 & 58 & 69.0 & 84 \\
Pirassununga & 26 & 31.0 & 162 & 67.5 & 240 \\
Ribeirão Preto & 78 & 32.5 & 28 & 47.5 & 59 \\
São Carlos & 31 & 52.5 & 625 & 62.5 & 1000 \\
São Paulo & 375 & 37.5 & 7 & 43.8 & 16 \\
Others* & 9 & 56.3 & 1212 & 61.6 & 1966 \\
Total & 754 & 38.4 & & & \\
\hline
\end{tabular}

*others centers outside the Campi 
Regarding income, the majority of participants (40.50\%) showed more than ten times the minimum wage $(\$ 2,325)$ per month. The results concerning the nutritional status indicated an average BMI of $23.78( \pm 3.98)$, corresponding to eutrophic. Overall, the majority $(63.3 \%)$ participants showed body weight within the normal range, $24.70 \%$ overweight and $6.40 \%$ obese grade I, however, when considered overweight and obese, we observed a total $32.30 \%$ of people.

Table 2. Comparison of the domains of quality of life between genders in the USP university community.

\begin{tabular}{llll}
\hline Domain & Gender & Median(AIQ) & p value \\
\hline Physical & Male & $75,00(17,85)$ & \\
& Female & $75,00(17,85)$ & 0,0539 \\
Psychological & Male & $70,83(16,66)$ & $0,0044^{*}$ \\
& Female & $70,83(20,83)$ & \\
Social Relations & Male & $66,66(16,66)$ & 0,1790 \\
& Female & $66,66(16,66)$ & \\
\hline Environment & Male & $65,62(18,75)$ & 0,1481 \\
& Female & $65,62(18,75)$ & \\
\hline
\end{tabular}

The results for the level of physical activity indicated a general average of METs (metabolic equivalents) of 2114.5
( \pm 3191.07). Regarding the classification of the IPAQ, $51.50 \%$ of subjects were considered active and $14 \%$ were very active, totaling $65.50 \%$ of people attending the recommendation of regular physical activity, in contrast to $34.50 \%$ of participants who did not meet minimum recommendation of regular physical activity.

The perception of QoL scores showed a 63.85 for the domain environment; 67.96 for the domain of social relations; 68.04 for the psychological domain; 73.03 for the physical domain, and 68.46 for the assessment of the individual about their overall QoL. Only in the psychological domain results indicate that there are statistically significant differences between genders, men have an average score of $69.15 \%$ against $67.35 \%$ for women (Table 2).

The values found for the Cronbach alpha coefficient $(\alpha)$ were as follows:

Total instrument $\alpha=0.82$ with 26 items;

Overall quality of life $\alpha=0.62$ with 2 items;

Physical domain $\alpha=0.76$ with 7 items;

Psychological domain $\alpha=0.78$ with 6 items;

Social relations domain $\alpha=0.70$ with 3 items;

Environment domain $\alpha=0.75$ with 8 items;

The results for domains of quality of life in relation to the level of physical activity (Table 3 ) indicate that individuals classified as very active have better perception of quality of life in the physical, psychological and environmental domains.

Table 3. Comparison of the domains of quality of life in the physical activity levels of the participants.

\begin{tabular}{|c|c|c|c|}
\hline Domain & Physical Activity Level & Median (AIQ) & Wilcoxon Groups $(\mathbf{a}=\mathbf{0 , 0 5})$ \\
\hline \multirow[t]{2}{*}{ Physical } & Sedentary & $75,00(17,85)$ & $\mathrm{B}$ \\
\hline & Insufficient Active B & $71,42(17,41)$ & $\mathrm{BC}$ \\
\hline KW: 39,5186 & Insufficient Active A & $69,64(21,42)$ & $\mathrm{C}$ \\
\hline \multirow{2}{*}{$\mathrm{P}:<0,0001$} & Active & $75,00(17,85)$ & $\mathrm{B}$ \\
\hline & Very Active & $78,57(14,28)$ & A \\
\hline \multirow[t]{2}{*}{ Psychological } & Sedentary & $66,66(20,83)$ & $\mathrm{BC}$ \\
\hline & Insufficient Active B & $66,66(16,66)$ & $\mathrm{C}$ \\
\hline KW: 33.6063 & Insufficient Active A & $66,66(20,83)$ & $\mathrm{C}$ \\
\hline \multirow[t]{2}{*}{$P:<0,0001$} & Active & $70,83(20,83)$ & $\mathrm{B}$ \\
\hline & Very Active & $75,00(16,66)$ & A \\
\hline \multirow[t]{2}{*}{ Social Relations } & Sedentary & $66,66(16,66)$ & $\mathrm{AB}$ \\
\hline & Insufficient Active B & $66,66(16,66)$ & $\mathrm{AB}$ \\
\hline KW: 5.1850 & Insufficient Active A & $66,66(25,00)$ & B \\
\hline \multirow[t]{2}{*}{ P: 0,2688} & Active & $66,66(16,66)$ & $\mathrm{AB}$ \\
\hline & Very Active & $75,00(25,00)$ & A \\
\hline \multirow[t]{2}{*}{ Environment } & Sedentary & $64,06(21,87)$ & B \\
\hline & Insufficient Active B & $62,50(15,62)$ & B \\
\hline KW: 19.1247 & Insufficient Active A & $62,50(18,75)$ & B \\
\hline \multirow[t]{2}{*}{ P: 0.0007} & Active & $65,62(18,75)$ & B \\
\hline & Very Active & $68,75(21,87)$ & A \\
\hline
\end{tabular}


Table 4. Facets of quality of life (scale 0-100\%).

\begin{tabular}{|c|c|c|c|}
\hline Domain & Facet & $\%$ & $\mathbf{D P}( \pm)$ \\
\hline General & 1. How would you evaluate your quality of life? & 77,4 & 15.6 \\
\hline General & 2. How satisfied are you with your health? & 72,0 & 18.2 \\
\hline Physical & 3. To what extent do you think your pain (physical) prevents you from doing what you need? & 81,6 & 19.2 \\
\hline Physical & 4. How much do you need any medical treatment to function in your daily life? & 84,2 & 18.2 \\
\hline Psychological & 5. How much do you enjoy life? & 72,2 & 15.0 \\
\hline Psychological & 6. To what extent do you think your life has meaning? & 81,6 & 17.2 \\
\hline Psychological & 7. How much can you focus? & 72,2 & 14.8 \\
\hline Environment & 8. How safe do you feel in your daily life? & 71,0 & 15.0 \\
\hline Environment & 9. How healthy is your physical environment (climate, noise, pollution, attractions)? & 65,6 & 16.0 \\
\hline Physical & 10. Do you have enough energy for your day-to-day? & 72,6 & 15,6 \\
\hline Psychological & 11. You are able to accept your bodily appearance? & 74,6 & 17.6 \\
\hline Environment & 12. Do you have enough money to satisfy your needs? & 67,2 & 17.8 \\
\hline Environment & 13. How available to you is the information you need in your day-to-day? & 80,2 & 14.0 \\
\hline Environment & 14. To what extent do you have opportunities of leisure activity? & 67,6 & 17.2 \\
\hline Physical & 15. How well are you able to get around? & 89,2 & 14.6 \\
\hline Physical & 16. How satisfied are you with your sleep? & 71,0 & 21.2 \\
\hline Physical & 17. How satisfied are you with your ability to perform your day-to-day activities? & 75,0 & 17.0 \\
\hline Physical & 18. How satisfied are you with your ability to work? & 75,0 & 17.2 \\
\hline Psychological & 19. How satisfied are you with yourself? & 73,6 & 17.4 \\
\hline Social Relations & $\begin{array}{l}\text { 20. How satisfied are you with your personal relationships (friends, relatives, acquaintances, } \\
\text { colleagues)? }\end{array}$ & 76,4 & 17.2 \\
\hline Social Relations & 21. How satisfied are you with your sex life? & 70,4 & 21.0 \\
\hline Social Relations & 22. How satisfied are you with the support you get from your friends? & 76,0 & 16.6 \\
\hline Environment & 23. How satisfied (a) you are the conditions of your living place? & 76,8 & 19.4 \\
\hline Environment & 24. How satisfied (a) you are with your access to healthcare? & 71,0 & 20.6 \\
\hline Environment & 25. How satisfied are you with your transport? & 68,6 & 23.6 \\
\hline Psychological & 26. How often do you have negative feelings such as blue mood, despair, anxiety, depression? & 71,8 & 16.8 \\
\hline
\end{tabular}

Note: categories followed by the same letter indicate no statistical difference between groups

For understanding the results of the WHOQOL BREF, Table 4 presents the average values of each facet that composes the instrument.

\section{Discussion}

This study presents characteristics of a group of volunteers from the university community of USP, located in different cities of São Paulo, Brazil. There was a substantial presence of women among the volunteers, given that the survey was developed with the voluntary participation, this result reinforces the idea that the female is concerned with the related QoL and health issues $(32,33)$.

The results for smoking were observed in the minority, and are similar to results found in cross-sectional study, population based, using data from the Survey of Health in São Paulo 2008 (ISA-Capital 2008), with 2,691 individuals both sexes and aged 12 or more, where a prevalence of $9.8 \%$ of smokers were identified (34). The low prevalence of smoking in relation to this and other studies like Patterson et al (35) and Holmen et al (36) was considered satisfactory and can be the result of the most recent national and state public policies to combat smoking, which brings contribution to the adoption of a healthier life style.

The present study noted a higher income than the national average in most volunteers, it is noteworthy that, in Brazil income distribution is very discrepant. Data from the
Household Budget Survey (HBS) from 2008 to 2009 indicated that the average family income per capita grew from R\$ 696.60 from 2002-2003 HBS to R\$ 838.60, an increase of $20.4 \%$ and this increase was proportionally higher in rural areas $(+36.20 \%)$ than in urban areas $(+19.10 \%)$ over the same period (37).

In association with the perception of QoL, Maciel et al (38) found that the higher the income of a university community, the greater the perception of QoL in the environment domain, reinforcing the assumptions that income plays an important factor in the perception of QoL especially regarding access to satisfying needs. Socioeconomic factors are definitely important and therefore reflect association with QoL especially when one considers the collectivities (39).

The results of the nutritional status of the volunteers in this research refer to behaviors that classify most as suitable. However when one considers the proportion of overweight and obese volunteers, was observed $32.30 \%$ of people with the potential risk of illness. A similar result was observed by Maciel (32) in the university community and below the HBS data from 2008 to 2009 that found that overweight among adults over 20 years almost tripled in men, going from $18.5 \%$ in $1974-1975$ to $50.1 \%$ in $2008-2009$, women in these indexes went from $28.70 \%$ to $48 \%$ (40).

Inadequate nutritional status is considered a serious health hazard because it compromises QoL, particularly with respect to physical, psychological and social relations domains which tends to worsen with the progression of 
years lived and during aging (41).

These data highlight the importance of formulating and implementing public policies focusing on practices promoting a healthier life style. Some studies suggest that modifying the patterns and eating habits is an effective strategy for the prevention of disease and promotion of QoL (42).

The present study identified the most active volunteers, although a substantial proportion of people $(34.50 \%)$ do not meet the minimum physical activity recommendations.

Despite scientific evidence of the benefits of regular physical activity, many people still adopt a sedentary behavior. Over 35 million people died in the year 2005 by some kind of NCDs that could be prevented with 30 minutes of regular physical activity of moderate intensity, 5 days a week (43).

The perception of QoL indicated by the volunteers showed the highest scores in the physical domain and the worst in the environment domain. Statistical differences between genders were seen only in the psychological domain. Maciel (32) found in research with college that men had better QOL than women in all fields differently from results found in this research.

For the domains of quality of life is important to note that the scale of the WHOQOL is a positive scale, ie, the higher the score, the better the quality of life. Therefore, it was found that the facet with the lowest value $(65.60 \%)$ is related to the environmental domain, facet 9 on the physical environment (climate, noise, pollution, attractions). Sequentially, one can list the facets: 12 - Do you have enough money to meet your needs? 14 - To what extent do you have opportunities for recreational activity? and 25 How satisfied are you with your transport?. With the worst scores in this study, interestingly all are facets of the environment domain, and present results below 70\%, these are items that negatively influence the perception of quality of life of the group studied.

Nevertheless, these items represent the daily difficulties that participants find, even in university environment, financial satisfaction, access to adequate transportation and leisure activities. Thus, despite being well above the national average income and being workers and students of one of the largest universities in Latin America, dissatisfaction with income, leisure and transport was evidenced by the group.

Moreover, the facets that have the highest score $(89.20 \%)$ refers to the physical domain, facet 15 - How well are you able to get around; followed by facet 4 , which is in need of some medical treatment to daily life; Facet 3 - To what extent do you think your pain (physical) prevents you from doing what you need? all the Physical Domain. Complementing this scale is facet 6 - psychological domain - To what extent do you think your life has meaning? and 13 facet of the environment domain - How available are to you the information you need in your day-to-day?, all these have scores above $80.0 \%$. By analyzing these results we believe that the facets that relate to physical autonomy favor the perception of quality of life, together with the meaning of life for these people and access to information. Given the characteristics of the participants these results could not be different.

Our results also indicated scores ranging from 62.50 (Domain Environment) to 78.5 (Physical Domain), these results are superior to those found by Branco et al (44). with employees of a university hospital, an average of 69.70 ( \pm 14.9) in the physical domain, $71.40( \pm 12.4)$ in the psychological domain, $73.60( \pm 15.8)$ in the field social relations and $54.10( \pm 9.4)$ in the domain that refers the environment and, in turn, are similar to the study of Costa et al. (45) evaluating the 136 college students on the psychology course in which the physical domain had the highest average (71.32) and the environment, the lowest (68.35).

The results of Oliveira; Guimarães (46) demonstrated among college students of the physical education course, that the physical domain and the environment showed the worse scores and possible justifications for such were argued on the fact that work as well as have more years of schooling, being older, being married, submit to shorter transportation to go to college, pay for college with their own resources, have car and are studying in the evening are significantly important variables for high quality of life in this sample, highlighting once again the importance of sociocultural context.

Similarly Custodio et al. (47) evaluated the quality of life of 150 university students distributed in Nutrition and Psychology courses and identified that the environmental domain had the worst results. When compared to each other it was noted that in general the students of nutrition tend to have a slightly better quality of life than those of psychology, and the students of the morning period have better quality of life in the environment domain, than those who study in nighttime.

Regarding the results of this study, although we have not considered courses of undergraduate students, but the participants as a whole, it is evident that even using a tool for evaluating subjective perception, there is a relationship between regular physical activity and positive perceptions on quality of life, because it is observed that, in the physical, psychological and environmental domains, individuals classified as very active presented results that differ statistically of the others, ie, they show positive perceptions from the quality of life in these areas.

In this sense, a study with 863 volunteers from the Catholic University of Pelotas community in the state of Rio Grande do Sul indicated that, of the total, $68.80 \%$ were single and $24.30 \%$ sedentary. The results showed, similarly to those found in this study, that the worst quality of life was observed in sedentary individuals. Added to that fact, sedentary adolescents are likely to become sedentary adults and, consequently, have a worse quality of life (48).

The authors point out that, despite not indicating a significant change at the intersection between physical activity patterns and social relationships domain; the highest averages are in active people in general, and the 
smallest in inactive people. The results found in this study are similar and deserve attention when one considers the increase in group activities and new personal interactions provided by the physical activities, so that this becomes an opportunity for social investment.

These results corroborate those from recent studies that share the idea that exercise is a low-cost intervention that can improve health in different aspects, from prevention and control of heart disease and other cardiovascular and metabolic alterations to the absence or few depressive symptoms or anxiety $(49,50,51)$.

It is understood that these results highlight the variability that can be found in the subjectivity of the concept and the individual perception of quality of life, it is noted however, that the social environment and the interests of the individual direct influence on the results and thus is of utmost importance that activities aimed at promoting an active lifestyle should be encouraged and developed in a university environment in order to consolidate more suitable habits for aging with better quality.

However, it is important to note that a limitation of this study is the lack of a probabilistic sampling system encompassing all units of the University in an equally and representative way to avoid a possible selection bias, since the voluntary participation can select naturally, who is more familiar with the issues.

If on one hand the use of the Internet for data collection presents itself as a viable resource, low cost and easy to use, it allows collecting data in geographically distinct points, also restricts the use on highly trained environments.

\section{Conclusions}

The study presents data from the university community. The assessed community can be considered as having a distinguished life pattern, considering that their income level is higher than the national average. The relationship of the biggest scores of domains of quality of life indicated by the more physically active is remarkable, although the other $34.50 \%$ classified as inactive or insufficiently active.

These data allow us to consider the value of physical activity as an efficient and low cost way for the promotion of quality of life in collectivities and therefore should be encouraged in view of the relatively low adherence programs aimed at a healthier lifestyle.

It is worth mentioning that the way the sample was selected, via the web, might have influenced the selection of people who have a higher propensity to participate in surveys, since many people do not have availability in filling out forms or even have had no time for that.

\section{Acknowledgements}

The authors are grateful for the financial support provided by FAPESP (São Paulo Research Foundation) and to CNPq (National Counsel of Scientific and Technological Development) for the scholarship provided.

\section{References}

[1] Minayo MCD S, Hartz ZMDA, Buss PM. Qualidade de vida e saúde: um debate necessário. Ciência Saúde Coletiva. 2000; 5(1): 7-18.

[2] WHO/FAO (Expert Consultation.Diet, Nutrition and the prevention of chronic diseases.Geneve. WHO (TechnicalReport Series, n.916), 2003.

[3] Group TW. The World Health Organization quality of life assessment (WHOQOL): development and general psychometric properties. Social nivers \& medicine. 1998; 46(12):1569-1585.

[4] Anokye NK, Trueman P, Green C, Pavey TG, Taylor RS. Physical activity and health related quality of life. BMC public health, 2012;12(1): 624 .

[5] WHO. WHO global strategy on diet, physical activity and health. Geneva, 2004. Disponível em: $<$ http://www.who.int/dietphysicalactivity/strategy/eb11344/s trategy_english_web.pdf.> Acesso em: 23 Out. 2013.

[6] Sonati JG, Vilarta R. Novos Padrões Alimentares e as Relações com os Domínios da Qualidade de Vida e Saúde. Novos padrões alimentares e as relações com os domínios da qualidade de vida e saúde. Campinas: IPES, 85-91; 2010.

[7] Maciel ES, Oetterer M. Alimentação e Atividade Física como Medidas de Políticas Públicas na Promoção da Saúde em Comunidade Universitária. Novos padrões alimentares e as relações com os domínios da qualidade de vida e saúde. Campinas: IPES,18-26.

[8] Bize R, Johnson JA, Plotnikoff RC. Physical activity level and health-related quality of life in the general adult population: a systematic review. Preventive medicine, 2007; 45(6): 401-415.

[9] Tyrovolas S, Panagiotakos DB (). The role of Mediterranean type of diet on the development of cancer and cardiovascular disease, in the elderly: a systematic review. Maturitas, 2010;65(2): 122-130.

[10] Rodriguez NR, DiMarco NM, Langley S. Position of the American dietetic association, dietitians of Canada, and the American college of sports medicine: nutrition and athletic performance. Journal of the American Dietetic Association, 2009;109(3): 509-527.

[11] Caria MA, Tangianu F, Concu A, Crisafulli A, Mameli O. (). Quantification of Spinning ${ }^{\circledR}$ bike performance during a standard 50-minute class. Journal of sports sciences, 2007;25(4): 421-429.

[12] O’Neil-Callahan K, Katsimaglis G, Tepper MR, Ryan J, Mosby C, Ioannidis JP, Danias PG. Statins decrease perioperative cardiac complications in patients undergoing noncardiac vascular surgerythe Statins for Risk Reduction in Surgery (StaRRS) study. Journal of the American College of Cardiology, 2005;45(3):336-342.

[13] Green AN, Paul DR, McGrath RP, Martinez V, Taylor K, Vella CA. Sedentary behavior, central obesity and cardiovascular disease risk factors in young women. International Journal of Exercise Science: Conference Proceedings 2013; (8):84. 
[14] Matsudo SM, Matdsudo VR, Araújo T, Andrade D, Andrade E, Braggion G. (). Nível de atividade física da niversit do Estado de Säo Paulo: análise de acordo com o gênero, idade, nível socioeconômico, niversitári geográfica e de conhecimento. Bras. Cienc. Mov, 2002;10(4): 41-50.

[15] Martin RJ, Dore ERIC, Twisk J, van Praagh E, Hautier CA, Bedu M. Longitudinal changes of maximal short-term peak power in girls and boys during growth. Medicine and nivers in sports and exercise, 2004; 36(3): 498-503.

[16] Galán I, Boix R, Medrano MJ, Ramos P, Rivera F, PastorBarriuso R, Moreno C. Physical activity and self-reported health status among adolescents: a cross-sectional population-based study. BMJ open, 2013;3(5).

[17] Caspersen CJ, Powell KE, Christenson GM. Physical activity, exercise, and physical fitness: definitions and distinctions for health-related research. Public health reports, 1985;100(2): 126-132.

[18] American College of Sports Medicine. Manual do ACSM para avaliação da aptidão física relacionada à saúde. Ed. Guanabara Koogan, Primeira edição, Rio de Janeiro 2006.

[19] Haskell WL, Lee IM, Pate RR, Powell KE, Blair SN, Franklin BA, Bauman A. Physical activity and public health: updated recommendation for adults from the American College of Sports Medicine and the American Heart Association. Circulation, 2007;116(9): 1081.

[20] Nelson ME, Rejeski WJ, Blair SN, Duncan P W, Judge JO, King AC, Castaneda-Sceppa C. Physical activity and public health in older adults: recommendation from the American College of Sports Medicine and the American Heart Association. Circulationn 2007; 116(9): 1094.

[21] Cox P. The Busy General Practitioner's Reference Guide to Increasing Physical Activity Levels in the British Population and Associated Benefits/Risks: A Review of the Literature. J Gen Pract, 2013; 1(101): 2.

[22] FÓRUM DE PRÓ-REITORES DE EXTENSÃO DAS UNIVERSIDADES PÚBLICAS BRASILEIRAS FORPROEX.Indissociabilidade ensino-pesquisa-extensão e a flexibilização curricular: uma visão da extensão. Brasília: $\mathrm{MEC} / \mathrm{SESu}, 2006$.

[23] Sonati JG, Modeneze DM, Vilarta R, Maciel ÉS, Boccaletto E, da Silva CC. Body composition and quality of life (QoL) of the elderly offered by the "University Third Age"(UTA) in Brazil. Archives of gerontology and geriatrics, 2011;52(1):e31-e35.

[24] ProFIS - Programa de Formação Interdisciplinar Superior. Site disponível em: http://www.prg.unicamp.br/profis

[25] Joly MCRA, Sisto FF, dos Santos AAA. Questões do cotidiano universitário. Casa do Psicólogo; 2005.

[26] UNIVERSIDADE DE SÃO PAULO - USP - Anuário estatístico - Disponível em: < $\mathrm{http} / / /$ sistemas3.usp.br/anuario/> Acesso em: 10 nov. 2010

[27] Booth ML, Ainsworth BE, Pratt M, Ekelund U, Yngve A, Sallis J F, Oja P. (2003). International physical activity questionnaire: 12-country reliability and validity. Medicine \& Science in Sports \& Exercise, 195(9131/03), 3508-1381.

[28] Pardini R, Matsudo S, Araújo T, Matsudo V, Andrade E, Braggion G, Raso V. Validação do questionário internacional de nível de atividade física (IPAQ-versão 6): estudo piloto em adultos jovens brasileiros. Bras. Ciên. E Mov. 2001; 9(3): 39-44.

[29] WHOQOL Group. WHOQOL User Manual.Geneva: 1998b.

[30] Fleck MP, Louzada S, Xavier M, Chachamovich E, Vieira G Santos L, Pinzon V. Aplicação da versão em português do instrumento abreviado de avaliação da qualidade de vida" WHOQOL-bref. Rev saúde pública, 200034(2), 178-83.

[31] Hair JF, Anderson R E, Tatham RL. Análise multivariada de dados. Bookman. 2007

[32] Maciel, É. D. S. (2006). Qualidade de vida: análise da influência do consumo de alimentos e estilo de vida (Dissertação de Mestrado em Ciências)- Escola Superior de Agricultura "Luiz de Queiroz", Universidade de São Paulo184p .

[33] Furlaneto CJ, Goulart RMM, Carmona RDM. A influência da Síndrome Metabólica sobre a qualidade de vida de pacientes em São Caetano do Sul The influence of the Metabolic Syndrome on the life quality of patients. Nutrire Ver. Soc. Bras. Aliment. Nutr, 2009;34(2): 85-99.

[34] Sousa CA, César CLG, Barros, MBA, Carandina LG Marchioni DML, Fisberg, R M. Prevalência de atividade física no lazer e fatores associados: estudo de base populacional em São Paulo, Brasil, 2008-2009. Cadernos de Saúde Pública, 2013; 29(2): 270-282.

[35] Patterson F, Lerman C, Kaufmann VG, Neuner GA, Audrain-McGovern J. Cigarette smoking practices among university college students: review and future directions. J Am Coll Health. 2004;52(5):203-10.

[36] Holmen TL, Barrett-Connor E, Clausen J, Holmen J, Bjermer L. Physical exercise, sports, and lung function in smoking versus nonsmoking adolescents. European Respiratory Journal, 2002;19(1): 8-15.

[37] Hoffmann R. Desigualdade da renda e das despesas per capita no Brasil, em 2002-2003 e 2008-2009, e avaliação do grau de progressividade ou regressividade de parcelas da renda familiar. Econ Soc, 2010;19(3): 647-61.

[38] Maciel EDS, Sonati JG, Modeneze D. M, Vasconcelos JS, Vilarta R. Food intake, nutritional status and level of physical activity in a Brazilian university community. Revista de Nutrição, 2012; 25(6): 707-718.

[39] Jakobsson U, Hallberg IR, Westergren A. Overall and health related quality of life among the oldest old in pain. Quality of Life Research, 2004;13(1): 125-136.

[40] INSTITUTO BRASILEIRO DE GEOGRAFIA E ESTATÍSTICA. IBGE. Diretoria de Pesquisas, Coordenação de Trabalho e Rendimento, Pesquisa de Orçamentos Familiares 2008-2009. Microdata: Rio de Janeiro, 2010.

[41] Crosetto MA, Acosta RS, Asaduroglu AV, Henain Y, Picech V, Ojeda S. Estado nutricional de adultos mayores niversitário de ver programa social ver componente alimentario implementado ver la ciudad de Córdoba. Año 2000. Rev. Fac. Cienc. Méd.(Córdoba), 2001;58(1): 29-48.

[42] Baldini M, Pasqui F, Bordoni A, Maranesi M. Is the Mediterranean lifestyle still a reality? Evaluation of food consumption and energy expenditure in Italian and Spanish university students. Public health nutrition, 2009;12(02): $148-155$. 
[43] MORBIDITY AND MORTALITY WEEKLY REPORT( MMWR) (2001). Increasing physical activity. A report on recommendations of the Task Force on Community Preventive Services,(50), 1214-1215.

[44] Branco JC, Giusti PH, Almeida AR, Nichorn LF. Qualidade de vida de colaboradores de hospital universitário do Sul do Brasil. J. Health Sci. Inst, 2010;28(1): 199-203.

[45] Costa CCD, Bastiani MD, Geyer JG, Calvetti PÜ, Muller MC, MoraesMLAD. Qualidade de vida e bem-estar espiritual em universitários de Psicologia; Calidad de vida y bienestar espiritual ver niversitários de Psicología; Quality of life and spiritual well-being in Psychology students. Psicol. Estud, 2008; 13(2): 249-255.

[46] Oliveira J, Guimarães, LAM. Qualidade de vida de estudantes universitários de Educação Física. PULSAR, 2009;1(2).

[47] Marconi EC, Gomes MR, Avoglia HR, Bastos I. Qualidade de vida entre universitárias: Estudos preliminares com o WHOQOL Bref. Boletim Academia Paulista de Psicologia, 2004;24(3), 47-57.

[48] Silva RS, Silva I, Silva RA, Souza L, Tomasi E. Atividade física e qualidade de vida. Cien Saude Colet, 2010;15(1): $115-120$.

[49] Maron BJ, Chaitman BR, Ackerman MJ, de Luna, AB, Corrado D, Crosson JE, Van Camp S P. Recommendations for physical activity and recreational sports participation for young patients with genetic cardiovascular diseases. Circulation, 2004;109(22): 2807-2816.

[50] de Mello MT, Boscolo RA, Esteves AM, Tufik S. O exercício físico e os aspectos psicobiológicos. Revista Brasileira de Medicina do Esporte, 2005; 197-207.

[51] Valim V. Benefícios dos Exercícios Físicos na Fibromialgia Benefits of Exercise in the Fibromyalgia. Bras Reumatol, 2006;46(1): 49-55. 